\title{
Jolanta Pivoriené⿱
}

(iD https://orcid.org/0000-0001-6328-7940

\section{Shierly Angelina Sungkono**}

iD https://orcid.org/0000-0001-9393-0933

\section{SOCIAL PRACTICES IN PROVIDING SOCIAL SERVICES FOR FAMILIES IN LITHUANIA: DAY CARE CENTERS APPROACH}

\begin{abstract}
Despite the considerable number of scientific papers on the importance of interactions between social workers and children in world literature, there are only a few studies and scientific papers in Lithuania that focus on the experience of social workers to interact with vulnerable children. The aim of this article is therefore to analyze the methods of interacting social workers with vulnerable children in daycare centers. Two research questions were formulated: what are the most effective and the least effective methods of interacting with sensitive children in the Vilnius daycare centers. The qualitative methodological approach was applied in the study. The data were collected through semi-structured interviews, which were analyzed using thematic analysis, which allowed for the separation of three main categories: common interaction methods, the most effective methods, and the least effective methods. The qualitative analysis of the data enabled, in turn, to indicate within the subcategories of the various activities to be able to rule on the effectiveness and functionality of group and individual therapy.
\end{abstract}

Keywords: interaction, individual work, group work, day care centre.

\section{Introduction}

Social work, as defined by the Ministry of Social Security and Labour of the Republic of Lithuania (2018) and in line with its universal definition approved by the International Federation of Social Workers (2014), is both a practicebased profession and an academic discipline that gives purposes to empower individuals, families, communities, and society in an effort to smoothen out human relationships and to liberate people from social problems through social change,

* Assoc. prof. dr., Mykolas Romeris University, Ateities str. 20, Vilnius, LT 08303, e-mail: jolantapiv@mruni.eu

** e-mail: esdi@mruni.eu 
social development, and social solidarity, on the basis of social work principles, which are centralised on social justice, collective responsibility, human rights, as well as respect for diversity. Based on the definition of social work, it is obvious that the nature of social work profession requires social workers constantly to interact with clients. Therefore, interaction becomes unavoidable and important in every aspect of social work and social work practice.

Child welfare system is one of the fields where social workers are employed. According to the official statistics provided by the Ministry of Social Security and Labour of the Republic of Lithuania (2018), there are in total of 285 children's day care centres for at-risk families and approximately 634 social workers working with vulnerable children and at-risk families in Lithuania. Danlope (2016) remarks that interaction between children and parents is helpful to shape children's thoughts and beliefs, providing them with a sense of self that helps determine characters and behaviours of the children in different situations. That said, vulnerable children often lack this opportunity, because of many possible reasons, such as misconduct or neglect by the parents. Social workers are frequently called in to fight for the rights of these children. The importance of social worker's contributions in vulnerable children's lives makes it necessary for social workers to have the capacity to approach and interact with these vulnerable children so that constructive relationships can be established between them. Therefore it is relevant to investigate interaction between social worker and vulnerable children in order to act at children best interests.

Social worker and children interaction is an interest of foreign scientific investigation. They highlight the importance of social worker's face-to-face practice with children and demonstrate the relevance of interaction between social workers and vulnerable children, describe tools used by social workers to effectively communicate with children (Miller 2018; Morrison 2016; Shemmings et al. 2018), analyse perspectives and experiences of children when they interact with social workers, stating that the quality of relationship between children and social workers plays a vital role in social work intervention (Oliver 2010). In spite of the abundance of scientific literature concerning the relevance of interaction between social workers and children worldwide, scientific studies that focus on social workers' experience of interaction with vulnerable children are still lacking in Lithuania. Therefore the goal of the article is to analyse social workers' interaction methods with vulnerable children at children's day care centres. Research object is interaction. These research questions are formulated: what are the most effective and what are the least effective methods of interaction with vulnerable children in day care centres in Vilnius.

Qualitative approach was chosen for investigation. Data was collected using semi-structured interviews, which consisted of 17 questions in total, covering the topic of social worker interaction with vulnerable children. Interview questions were divided into four categories: social workers' relationship with vulnerable 
children, challenges of interaction, interaction methods, and coping methods. In this article one (interaction methods) out of four sets of questions is analysed. After transcribing all interviews, they were analysed by using thematic analysis approach, which revealed these categories: typical interaction methods, the most effective methods, the least effective methods.

Research participants were selected by using purposive sampling by these criteria: currently work as social worker in children day care centre in Vilnius; have at least one year experience of direct interaction with vulnerable children. Contacts were gathered from Vilnius City Administration official website, providing a complete list of 28 children's day care centres for at-risk families located in Vilnius. After invitation emails and follow-up phone calls 9 female social workers from different centres agreed to participate in the interviews.

In order to meet ethical requirements, verbal consent regarding confidentiality of personal identity and the social worker's workplace was clarified to each research participant. The research participants were also clarified that since their participations were voluntary, therefore, they were free to decline any questions that they felt uncomfortable to answer to. All research participants agreed about their interviews being recorded. Each research participant was given identification code started with SW, which is the abbreviation for Social Worker, followed by number from 1 to 9 .

\section{Understanding characteristics of interaction and methods of interaction}

Interaction, in this context, is interpreted distinctly as social interaction, referring to the occasion when two or more people communicate with or react to each other, e.g. a process of how we act and react to the people around us (Moffitt 2018). Morgan (2015) suggests that we are in our most comfortable selves when we are in good terms with others.

Human interaction can be differentiated into two types: focused interaction and unfocused interaction. Focused interaction is understood as an interaction that occurs between two or more people that have a common goal (e.g.: a group of children preparing for a lunch together with their social worker), on the other hand, unfocused interaction refers to an interaction between individuals who does not have either any familiarity or a common goal (e.g.: interaction between pedestrians who try not to be involved in accident by following the traffic rules). Additionally, interaction itself can be classified as either conjunctive, which is an interaction that bring people together, or disjunctive, which is an interaction that pull people apart (Bardis 2014). In social work practice in the field of child welfare, focused interaction is applied to describe the day-to-day interaction between social workers and children, due to both social worker and the child are usually having the same 
goal to achieve, which is mainly to reduce the vulnerability encountered by the children and to protect them from further harm. Also there is striving that most of interactions would be of conjunctive manner.

Social workers in child welfare interact with children in a variety of ways, which can be in the form of either individual interaction or group interaction. Individual interaction occurs when social worker is required to provide assessments, to obtain a detailed information from a child regarding their needs or goals, to provide individual counselling or psychotherapy, or to advocate for children that are unable to speak up for themselves, such as children with severe disabilities. On the other hand, group interaction occurs when social worker provides group counselling, group seminars, or group activities that require participation of some or all children (Miller 2018).

In order to have a meaningful interaction, an effective communication with children and possibility to apply various methods social workers, apart from the core social work skills, must also have these particular skills, such as capabilities to form trusting relationships, to grasp non-verbal communication, to listen attentively, to build relationship with the children, to discuss different kinds of issues, to provide information for children, to give a clear feedback to the children, to emphasise children's perspectives about any situation, and to explain confidentiality and boundaries. In addition, during interaction, social workers must also believe that children are competent in sharing information that can contribute in assessment process, planning, decision making (Research in Practice 2014). UNICEF (2018) clarifies that the ability to effectively interact and communicate with children will extensively help social workers gain information from the children, as effective communication will enable the children to communicate and express their concerns and needs, thus social workers can better protect and assist the children if the main concerns of the children have been clarified, in addition, the ability of social worker to be truthful and accurate when interacting with children is proven to empower children in making appropriate decisions and choices for themselves. UNICEF argues that it will not be possible to determine the best interest of any child without having a direct and effective interaction and communication with the child him/herself. Therefore, it is important for social workers to understand the essence of interaction so that they can critically assess the characteristics of interaction, whether the interaction itself will lead to more troubles or fix the troubles. Morrison (2016) stated that when children spend enough time to interact with their social worker, it would be easier for children to develop trust in their social worker, thus it would be easier for social workers to discuss sensitive issues with the children. 


\section{Interaction methods with vulnerable children in day care centres in Lithuania}

Research data analysis revealed these categories in the theme Social work interaction methods: typical interaction methods, the most effective methods, the least effective methods.

In the category Typical interaction methods these sub-categories are formulated: group work, individual work, active listening, humour.

Findings revealed that the most common methods used to interact with children in day care centres are through group work activities due to the great number of children attending day care centres and limited number of social workers working in per day care centre. SW2 clarified, ...our place is not suitable for individual consultation... it's really open and always crowded. Playing interactive games, role-playing, sports, excursions, camps, art therapy, celebrations, group reflection, discussions, cooking, having lunch, activity scheduling, psychoeducation, social skills activities are mentioned among typical group activities (A lot of playing... it helps to communicate... play a lot of different games... excursions, riding a bike... playing bowling, going to the cinema... (SW1); ... art therapy, painting with the goal to express feelings... excursions... we go to some kind of local area, forest, for some activities... volunteering... we celebrate birthdays and other important events (SW2); ...made a schedule about activities we can do with them (SW3); ... art therapy... drawing... music therapy... board games... we have a goal that children express in the better way than fighting... by making them do sports... basketball... team games... celebrate birthdays... eat together... summer school... excursions ... cinema ... skiing... (SW4); ... games inside, games outside in the yard, playing football, lunch when we are cooking together, social skills activities, sport games (SW5); ...games, plays, art therapy, play with dolls... we play families... in such a way, they can act situation of what happens in their house... we have one week of summer camp... boxing... (SW7); ...learning through experience... reflection... (SW8); ... group methods... arts and sports... (SW9)).

Individual work is used when group work can't be applied ....if a child can't be in a group because of violence or other things, we do individual work with that child... individual consultation (SW2). Reading books, individual consultations, doing homework, rewards, individual reflection are mentioned as individual work activities. Reward/motivation system seeing that each child has their own pluses and minuses according to their day-to-day behaviours, is implemented daily in the day care centres: ...reward system. They collect pluses and minuses... (SW2); You try to help them but they would learn themselves to do stuff... we have pluses for homework... if they help someone. If they participate... (SW6). The method of reward/motivation system is proven to be a good method to teach children how to be responsible. Children tend to show their best behaviours because they want something in return, prizes, for instance. 
Active listening (A lot of active listening... so they feel that you understood them. (SW1)) and humour (...humour... for some situations you need to do some jokes... it's important for children (SW1); ...some children are very good with humour (SW9); Ifeel that sense of humour now in day care centre is very strong thing and children are using this (SW4)) also fall in the category of typically applied methods.

In the category the most effective interaction methods to apply these subcategories are formulated: group work activities, reward system, reflection, listening. These methods are beneficial to get to know the children better, to understand children, to create relationship with children, as well as to increase children's participation in activities (...through games... we learn how to be in the group... how to be in society... it's also coping mechanism. They deal with emotions (SW8), ...play and group work, which involve all. The goal is that when all participate... this group really likes artwork... they always participate... (SW2), ...group work, games outside, and social skills activities. They help create relationship with children and to know more about them... (SW5)). SW8 suggested that these methods are also beneficial to help children ...learn how to be in the group... how to be in society. It's also coping mechanism. They deal with emotions. If something is happening in their house, they can play, act, and it's less stressful for them. Among the most effective group work activities are mentioned: art therapy, picture taking, outdoor games, social skills activities, games. As the most effective methods from individual work reward system (...about plus and minus help us because they become more responsible and they understood that nothing is easy and for free... help us have more respect (SW3)) and reflection (... reflecting individually... to have individual interaction (SW8)) are emphasised. From typical interaction methods also listening is defined as the most effective method of interaction (...listening and wanting to understand. It's important (SW1), ... to listen and to feel each other, and to pay attention to children (SW2)).

In the category the Least effective interaction methods these sub-categories are formulated: strict discipline, talent show, watching movies, handcrafting and going to museums. Social workers were asked about the least effective methods; method that they don't apply anymore because it doesn't work in their day care centres. Social workers said that strict discipline is the least effective method to create a positive relationship with children. SW9 commented: ... if you always be policeman, or very strict and very controlling. It's not helping. Other the least effective methods include psychoeducation (I tried a little bit of psychoeducation... They didn't want that and they were not so excited... 10 times, then I stopped because it kind of ruined our contact (SW1)), talent show (...like singing and expressing their singing to others... everything goes wrong because everyone gets shy... it doesn 't work (SW2)), watching movies (...there are different groups of children... they cannot watch one movie together... (SW5)), handcrafting (...handcraft, they don't like such things (SW7)), going to museums (...going outside to museum, they become aggressive and can be very noisy (SW7)). 
Summarising it could be said that individual work and group work are applied in all researched day care centres, although social workers prefer to use more group work than individual work. Various group work activities dominate in the most effective and the least effective interaction methods lists, while individual group activities are mentioned only as effective interaction activities. Thus focused social workers and children interaction in group work form could be both conjunctive and disjunctive depending on specific situation and interaction activities applied.

\section{Conclusions}

Social workers working in child welfare system have regular professional interactions with children and therefore have to have high competence in interaction and ability to apply various interaction methods for the best interest of the child. Many scientific researches indicated that the way social worker interacts with children contributes to children development and well-being.

To help create positive relationship with the children, social workers use two different interaction methods: individual work and group work. Group work is applied not mostly for professional but because of structural reasons at day care centres: big number of children and small number of social workers. Individual work is used in marginal situations.

Social workers see group work activities as more effective interaction methods than individual ones. Art therapy, picture taking, outdoor games, social skills activities, games are seen as the most effective group activities in day care centres. From individual work reword and reflection are defined to be effective. The least effective interaction methods are listed from group work activities.

\section{References}

Bardis P.D. (2014), Social Interaction and Social Processes, "Pi Gamma Mu, International Honour Society in Social Sciences and JSTOR", no. 54(3), retrieved from: http://www.leedugatkin. com/files/2214/1304/6015/Bardis.pdf (accessed 1.06.2019).

Calder M., McKinnon M., Sneddon R. (2012), National Risk Framework to Support the Assessment of Children and Young People, retrieved from: http://hub.careinspectorate.com/ media/109497/sg-national-risk-framework-to-support-assessment.pdf (accessed 1.06.2019).

Danlope I. (2016), The Role of Social Interactions in Social Psychology, retrieved from: https://www. linkedin.com/pulse/role-social-interactions-psychology-isaac-danlope (accessed 1.06.2019).

Espejo K. (2016), The Benefit of Numbers: Group Therapy for Children and Adolescents, retrieved from: https://www.childandfamilymentalhealth.com/the-benefit-of-numbers-group-therapyfor-children-and-adolescents/ (accessed 1.06.2019).

International Federation of Social Work (2014), Global Definition of Social Work, retrieved from: http://ifsw.org/policies/definition-of-social-work/ (accessed 29.05.2019).

Miller A. (2018), How Does a Social Worker Interact?, retrieved from: http://work.chron.com/ social-worker-interact-21606.html (accessed 1.06.2019). 
Ministry of Social Security and Labour of the Republic of Lithuania (2018), Even More Children Will Be Able to Attend Children's Day Care Centres, retrieved from: https://socmin.lrv.lt/lt/ naujienos/dar-daugiau-vaiku-gales-lankyti-vaiku-dienos-centrus (accessed 29.05.2019).

Ministry of Social Security and Labour of the Republic of Lithuania (2018), Social Work and Regulation, retrieved from: https://socmin.lrv.lt/en/activities/social-integration/social-servicesand-social-work/social-work-and-regulation (accessed 29.05.2019).

Ministry of Social Security and Labour of the Republic of Lithuania (2018), Statistic, retrieved from: https://socmin.lrv.lt/lt/veiklos-sritys/seima-ir-vaikai/vaiko-teisiu-apsauga/statistika-1 (accessed 29.05.2019).

Moffitt K. (2018), Social Interaction, retrieved from: https://study.com/academy/lesson/socialinteractions-definition-types-quiz.html (accessed 1.06.2019).

Morgan N. (2015), We Humans Are Social Beings - and Why That Matters for Speakers and Leaders, retrieved from: https://www.forbes.com/ (accessed 1.06.2019).

Morrison F. (2016), Social Worker's Communication with Children and Young People in Practice, retrieved from: https://www.iriss.org.uk/resources/insights/social-workers-communicationchildren-and-young-people-practice (accessed 1.06.2019).

Oliver C. (2010), Children's Views and Experiences of Their Contact with Social Workers: A Focused Review of the Evidence, retrieved from: http://dera.ioe.ac.uk/11515/1/Children_s_views_and experiences_of_contact_with_social_workers_report_July_2010.pdf (accessed 1.06.2019).

Research in Practice (2014), Communicating Effectively with Children and Young People, retrieved from: http://fosteringandadoption.rip.org.uk/topics/communicating-effectively/ (accessed 1.06.2019).

Shemmings D. et al. (2018), Tools Social Workers Can Use to Talk to Children, retrieved from: $\mathrm{http}: / / w w w . c o m m u n i t y c a r e . c o . u k / t o o l s-s o c i a l-w o r k e r s-c a n-u s e-t o-t a l k-t o-c h i l d r e n /$ (accessed 1.06.2019).

Sinner P. et al. (2018), What are Some Good Approaches to Conducting Focus Groups with Children?, retrieved from: http://www.lse.ac.uk/media-and-communications/assets/documents/research/eukids-online/toolkit/frequently-asked-questions/FAQ-34.pdf (accessed 1.06.2019).

The United Nations of Children's Fund (2018), Foundations Working with Children, retrieved from: https://www.unicef.org/violencestudy/pdf/ARC_working_with_children.pdf (accessed 29.05.2019).

Vilnius City Administration (2019), Vaiku Dienos Centrai, retrieved from: https:/www.vilnius.lt/lit/ Vaiku_dienos_centrai/9118276 (accessed 29.05.2019).

\section{Jolanta Pivorienè \\ Shierly Angelina Sungkono}

\section{PRAKTYKI SPOLECZNE W ŚWIADCZENIU USLUG SOCJALNYCH DLA RODZIN NA LITWIE: CENTRA OPIEKI DZIENNEJ}

\footnotetext{
Abstrakt. Pomimo znacznej liczby opracowań naukowych dotyczących znaczenia interakcji między pracownikami społecznymi a dziećmi w literaturze światowej, to na Litwie niewiele jest takich badań i artykułów naukowych, które koncentrują się na doświadczeniu pracowników socjalnych w zakresie interakcji z dziećmi wrażliwymi. Celem tego artykułu jest zatem przeanalizowanie metod interakcji pracowników socjalnych z dziećmi podatnymi na zagrożenia w ośrodkach opieki dziennej. Sformułowano dwa pytania badawcze: Jakie są najskuteczniejsze, a jakie najmniej skuteczne metody interakcji z dziećmi wrażliwymi w ośrodkach opieki dziennej w Wilnie? W badaniu
} 
zdecydowano się na wybór podejścia jakościowego. Dane zebrano za pomocą częściowo ustrukturyzowanych wywiadów, które przeanalizowano za pomocą analizy tematycznej, co pozwoliło na wyodrębnienie trzech głównych kategorii: typowe metody interakcji, najskuteczniejsze metody i najmniej skuteczne metody. Analiza jakościowa danych umożliwiła z kolei wskazanie w ich obrębie podkategorii odnoszących się do różnych działań i aktywności, aby móc orzekać o skuteczności i funkcjonalności terapii grupowej i indywidualnej.

Słowa kluczowe: interakcja, indywidualna praca, praca grupowa, centrum opieki dziennej. 